COVID-19 PANDEMISINDE AKUT İSKEMIK İNME TEDAVISİ: UZMAN GÖRÜŞÜ

\title{
ACUTE ISCHEMIC STROKE TREATMENT IN COVID-19 PANDEMIA: EXPERT OPINION
}

\author{
Mehmet Akif TOPÇUOĞLU' ${ }^{1}$, Ethem Murat ARSAVA ${ }^{1}$, Atilla Özcan ÖZDEMİR ${ }^{2}$ \\ 1Hacettepe Üniversitesi, Tıp Fakültesi, Nöroloji Anabiim Dalı, ANKARA \\ 2Eskişehir Osmangazi Üniversitesi, Tıp Fakültesi, Nöroloji Anabilim Dalı, ESKIŞEHİR
}

\begin{abstract}
Anahtar Sözcükler: COVID-19, pandemi, akut iskemik inme, trombolitik, bulaş, korunma. Keywords: COVID-19, pandemia, acute ischemic stroke, thromboliytic, contamination, protection.
\end{abstract}

\section{GİRIS}

Koronavirüs Hastalığı 2019 (COrona VIrus Disease 2019; COVID-19) pandemisinin ülkemiz dahil dünya genelinde çok ciddi bir tehdit oluşturduğu dönemde bu görüş yazısını kaleme alıyoruz. Pandemi günlerinde konsantrasyonumuz ve imkanlarımız akut inme tedavisi de dahil olmak üzere diğer hastalıklardan korona virüs enfeksiyonlarına kaymış izlenimi veriyor. Ancak, akut inmenin ne sıklığı azald, ne de sonuçları ve tedavisi değiști. Bu nedenle diğer acil ve kritik durumlar gibi akut iskemik inme de bu dönemde tedavi edilmeye devam edilecektir.

\section{COVID-19 İNMEYE YOL AÇAR MI?}

Mevcut bilgilere göre COVID-19 viremisi "doğrudan" iskemik inme nedeni olarak görünmemektedir. Ama diğer enfeksiyon süreçlerinde olduğu gibi farklı patofizyolojik mekanizmalar ile iskemik inmeyi tetikleyebilir $(1,2)$. COVID-19 hastalarında \%6'ya varan oranda, yani artmış sıklıkta, inme görüldüğü bildirilmiștir. Hastaların daha çok ileri yaş grubunda olmaları ve çoklu komorbiditelerinin varlığı nedeniyle sıklığın artmış olabileceği hemen düşünülebilir. Diğer taraftan, ağır pnömoni ve COVID-19'a yola çan yeni tip korona virüse [Severe Acute Respiratory Syndrome coronavirus; SARS-CoV-2] bağlı akut ağır solunum yetmezliği sendromunun ilerleyip kontrolü güç seviyeye ulaşması ile çoklu organ yetmezliği ve sepsistekine benzer koagülopati, yaygın intravasküler koagülasyon veya kardiyak etkilenimin sürece eklenmesi ile de inme riski artabilir. Daha hafif COVID süreçlerinde de koagülopatinin hem hemorajik hem de iskemik inmeyi artırma potansiyeli üzerinde durulmaktadır (3). Kısacası, böyle bir risk vardır, ama bugüne kadar ayrıntılı araştırılma fırsatı yakalanamamıștır. Bunun yanında SARS-CoV-2'nin nörotropizm potansiyeli olan bir virüs olduğu akıllarda kalmalıdır $(4,5)$.

Diğer taraftan COVID pandemisinde Çin kaynaklı serilerde hastaların yaklașı üçte birinde nörolojik semptomların bulunduğu ifade edilmiştir (6). Hatta bir kısminda bu semptomlar pulmoner bulgulardan öncedir. Nörolojik tablolar ve yaklaşık görülme sıklıkları seriler arasında geniş farklılıklar olmakla birlikte şu şekildedir: baş dönmesi [\%20]; baş ağrısı [\%15], kas hasarı [\%10], anosmi [\%5], disguzi [\%6] ve ensefalopati [\%3].

Enfeksiyon şiddeti arttıkça nörolojik semptomatoloji de artar. Ama bazı hastalarda

\footnotetext{
Yazışma Adresi: Prof. Dr. Mehmet Akif Topçuoğlu, Hacettepe Üniversitesi Tıp Fakültesi, Nöroloji Anabilim Dalı, 06100, Sıhhiye, Ankara

Telefon: $03123051806 \quad$ E-posta: matopcuoglu@yahoo.com

Tüm yazarlar ORCID ID: Mehmet Akif Topçuoğlu 0000-0002-7267-1431, Ethem Murat Arsava 0000-0002-6527-4139, Atilla Özcan Özdemir 0000-00029864-6904

Bu makale șu şekilde atıf edilmelidir: Topçuoğlu MA, Arsava EM, Özdemir AÖ. COVID-19 pandemisinde akut iskemik inme tedavisi: uzman görüșü. Türk Beyin Damar Hastalıkları Dergisi 2020; 26(1): 91-94. doi: 10.5505/tbdhd.2020.62134
} 
enfeksiyon belirgin olmaksızın nörolojik bulgular olabilir (6). Haliyle, bu semptomların bir kısmı yeterli anamnez alınamayan durumlarda inme taklitçisi olarak ele alınmış olabilir. Bu dönemde inme ayırıcı tanısında azami dikkat şarttır. Acil tıp ve enfeksiyon uzmanlarının SARS-CoV-2'nin bu tarz atipik prezentasyonu olduğunu da her zaman hatırlarında tutmaları gerekir. Bu yakınmalarla gelen her hasta potansiyel bir COVID hastadır ve buna göre muamele edilmeyi gerektirir (3).

\section{AKUT INME HASTASININ ILK DEĞERLENDİRILMESİ NASIL OLMALIDIR?}

Akut inme hastalarında sıklıkla COVID-19 risk ve mevcudiyeti açısından anamnezin yeterli netlikte alınamaması söz konusudur. $\mathrm{Bu}$ nedenle her hasta potansiyel olarak SARS-CoV-2 ile enfekte kabul edilmeli, ve uygun şekilde bu enfeksiyon ekarte edilinceye kadar tam kișisel korunma ekipmanı ile muayene edilmelidir (7-9). Kurumda bu temel şart sağlanamıyorsa hasta ile uygun şartlarda kontakt sağlayan hekim [bu sıklıkla acil tıp uzmanı olacaktır] ile [kurum içi] telemedikal konsültasyon yapılması gerekir ve önerilir (7).

Bunun dişında inme hastası mevcut kılavuz ve düzenlemelere uygun şekilde değerlendirilir. Pandemi akut inme yönetimi ve kalite metriklerinde değişiklik veya esnemeye yol açmaz ve açmamalıdır $(7,10,11)$.

\section{AKUT İNMEDE TEDAVİ PLANI OLUŞTURULMASI}

Akut iskemik inme tedavisi uygulama prensipleri SARS-CoV-2 ile enfekte veya enfeksiyon şüphesi bulunan hastalarda değişiklik göstermez. Ancak pandemi dönemine ait özel önlemlerin alınması gereklidir. Bunlar tabloda özetlenmiștir.

Akut iskemik inmede IV tPA uygulaması yapacak ekibin tam kişisel koruma ekipmanı kullanması ve kontakt güvenliği kurallarına azami uyumu şarttır $(9,12)$.

Akut iskemik inme hastası prosedürel amaçla entübe edilecek ise bunun pandemi kuralları içinde yapılması gerekir (8). Bu işlemin anjiografi suitine veya nöroloji birimlerine bırakılmaması ve negatif basınçlı ortamlarda en tecrübeli uzmanlarca ve pandemi şartları çerçevesinde gerçekleştirilmesi mutlak bir zorunluluktur (11). Girişimsel işleme alınacak her hasta için düşük doz toraks BT ve SARS-CoV-2 PCR testi yapılmalıdır.
Test sonucu elbette daha sonra elde olunacaktır, ancak bu işlem sonrası hastanın nerede izleneceği kararı açısından kritik önem taşır.

Toraks BT oldukça yüksek duyarlılıkla [>\%95] yeni korona enfeksiyonu bulgularını gösterir (13). Prosedüre başlama için spesifisite de önemli olmakla birlikte şüphe halinde vaka COVID19 pozitif olarak işleme alınır.

\section{AKUT TEDAVI SONRASI SÜREÇ}

Akut iskemik inme hastaları sistemik trombolitik tedavi veya girişimsel işleme girdikten sonra doğrudan inme ünitesi veya nöroloji yoğun bakım ünitesine gidecek ise bu ünitelerin COVID19 açısından tam bir yeterliliğe sahip olması gerekir. Bu şart tam anlamıyla sağlanamıyor ise hastalar COVID-19 ekarte edilene kadar bu şartların sağlandığı başka ünitelerde tutulur, ve test[ler]in negatif çıkması ve enfeksiyonun ekarte edilmesini takiben adı geçen ünitelere transfer edilir.

Durumu iyi olan, Toraks BT'sinde COVID enfeksiyonu lehine hiçbir bulgusu olmayan ve PCR çalışması negatif olan hastaların 24 saat yoğun bakımda izlenmesi şart değildir. Bu hastalar diğer nöroloji birimlerinde izlenebilir (14).

Ekstübe olamayan veya nörolojik durumu nedeniyle nörolojik yoğun bakım ünitesinde takibi gereken hastalar ilk olarak kabul edildikleri COVID için kompetan ünitelerde toraks BT ve PCR sonuçları negatif saptandıktan sonra nöroyoğun bakım ünitelerine transfer edilir, ve orada izlenmeye başlanırlar.

Durumu belirsiz hastalar anjiografi suiti, inme ünitesi veya nöroloji yoğun bakım ünitelerinde ekstübe edilemezler. Anjiyo suitinde endovasküler tedavi sırasında hekimler kişisel koruma ekipmanlarını hastayı sanki COVID-19 hastasıymış gibi kabul ederek kullanmalılardır. Anjiyo süitinin havalandırma sistemi mutlaka kontrol edilmeli ve ameliyathanedeki şartlar gibi hazırlanmalıdır.

\section{INME HASTASINDA COVID-19 ENFEKSIYONU RÍSKi}

İnme hastası yatırıldıktan sonra aspirasyon pnömonisi veya idrar yolu enfeksiyonu gibi enfeksiyonlar veya diğer nedenlerle ateş çıkması ile çok sık karşılaşılmaktadır. Bu durumlarda hızla SARS-CoV-2 enfeksiyonu da ekarte edilmelidir (7). 
Tablo. Akut iskemik inme tanı tedavi algoritmalarına pandemide yapılması önerilen ilaveler $(9,12,16-18)$.

\begin{tabular}{|c|c|c|}
\hline & Potansiyel inme olgusu & \\
\hline Aşama-1 & $\begin{array}{l}\text { Enfeksiyon kontrol taraması için aşağıdaki sorular sorulur. } \\
\square \text { Hastada ateş, öksürük, göğüs ağrısı, nefes darlığı, baş ağrısı, miyalji, bulantı } \\
\text { / kusma, diyare veya başka enfeksiyöz semptom var mı? } \\
\square \text { Enfeksiyon semptomu veya tanısı olan şahıs ile temas öyküsü var mı } \\
\text { [Sağlık Bakanlığı rehberinde tarif edilen her derecede temas]? } \\
\square \text { Hastanın veya temas öyküsü olan kişilerin seyahat öyküsü pozitif mi? } \\
\square \text { COVID-19 pandemi kurallarına yetersiz uyum şüphesi var mı? } \\
\square \text { Herhangi bir pandemi hastanesine son } 14 \text { gün içinde herhangi bir nedenle } \\
\text { gitmiș mi? }\end{array}$ & $\begin{array}{l}\text { Bu sorulardan en az } \\
\text { birinin yanıtı "EVET" } \\
\text { ise KORUMALI İNME } \\
\text { PROTOKOLÜ'ne geçilir. }\end{array}$ \\
\hline \multirow[t]{4}{*}{ Aşama-2 } & $\begin{array}{l}\text { Aşama-1'deki soruların hepsi negatif ise aşağıdaki sorular sorulur. } \\
\square \text { Hastadan [veya yakınından] alınan hikâyede yeterlilik veya güvenilirlik } \\
\text { sorunu var mı? } \\
\square \text { Afazi veya bilinç kapalılığı gibi iletişimi bozan durumlar var mı? } \\
\square \text { Anamnez ve bulgular inme dışı hastalıklarla uyumlu mu? }\end{array}$ & $\begin{array}{l}\text { Bu sorulardan en az } \\
\text { birinin yanıtı "EVET" } \\
\text { ise KORUMALI İNME } \\
\text { PROTOKOLÜ'ne geçilir. }\end{array}$ \\
\hline & $\begin{array}{l}\text { Korumalı inme protokolü } \\
\text { Aerolizasyon [Havaya (mikro)damlacık karışması] veya riski var mı? } \\
\text { Kusma, öksürük, aksırma, sekresyon, orofaringeal veya nazal aspirasyon } \\
\text { ihtiyacı veya yapılması, nebülizasyon, nazo/oro-enterik tüp veya beslenme } \\
\text { tüpü takılması, entübasyon, non-invaziv mekanik ventilasyon, kardiyo- } \\
\text { pulmoner resusitasyon vs. varsa [olasılı̆̆ı dahil] veya benzeri durumlarda } \\
\text { aerolizasyon riski vardır. Bu işlemlerden sadece mutlak gerekenler } \\
\text { yapılmalıdır. } \\
\square \text { Aerolizasyon riski yoksa kişisel koruma ekipmanı uygun şekilde giyilir. } \\
\text { Uzun kollu ameliyathane önlüğü, cerrahi maske, geniş gözlük, bone, siperlik } \\
\text { ve eldiven minimumdur. Aerolizasyon riski var ise buna uygun kişisel } \\
\text { koruma ekipmanı kullanılır. Bu N95 maske ve uzun eldiven eklenmesini } \\
\text { içerir. N95 maske üzerine cerrahi maske takılır. } \\
\square \text { El hijyeni protokolüne [zamanlama ve teknik] eksiksiz uyum esastır. } \\
\square \text { Entübe olmayan her hastaya cerrahi maske takılır. Bu tetkikler ve } \\
\text { transferler esnasında çıarılmaz. } \\
\square \text { Hastanın bilinç durumu geri veya geriliyor ise, nörolojik endikasyon varsa, } \\
\left.\text { işlemler esnasında yüksek oksijen [FiO }{ }_{2}>0,5\right] \text {, CPAP, BIPAP, HFOT veya ambu } \\
\text { ihtiyacı olabilecek ise tetkike gitmeden önce acil / yoğun bakım uzmanına } \\
\text { haber verilir ve erken entübasyon uygulanır. Suboptimal şartlarda } \\
\text { entübasyon yapılması zorunda kalınması ciddi risk oluşturur. }\end{array}$ & \\
\hline & Korumalı inme protokolü - Tedavi sonrası & \\
\hline & $\begin{array}{l}\square \text { IV tPA uygulaması yapılan hastalar [Toraks BT “non-COVID” olup klinik } \\
\text { olarak da uygun hastalar] COVID-19 PCR negatif gelince inme ünitesine veya } \\
\text { nöroloji servisine yatırılır. } \\
\square \text { IV tPA uygulaması yapılan hastalar [Toraks BT “non-COVID” olup klinik } \\
\text { olarak nöroyoğunbakım gerektiren hastalar] COVID-19 PCR negatif gelince } \\
\text { Nöroloji yoğun bakıma çekilir. } \\
\square \text { Trombektomi yapılan hastalar [Toraks BT "non-COVID” olup PCR negatif } \\
\text { olan hastalar] nöroloji yoğun bakıma yatırılır. } \\
\square \text { İnme ünitesinde ve nöroloji yoğun bakımda aerolizasyon koruması } \\
\text { olmadığı durumlarda hastalar ancak COVID-19 varlığı ekarte edilince bu } \\
\text { ünitelere alınabilirler. Bu açıdan Toraks BT ve PCR yeterli olup, pozitif } \\
\text { hastaların COVID ünitelerine, negatif hastaların ise Nöroloji birimlerine } \\
\text { triyajı uygundur. }\end{array}$ & \\
\hline
\end{tabular}




\section{SONUÇ}

COVID-19 pandemisi sırasında akut inme tedavisi protokolü modifiye edilmelidir. $\mathrm{Bu}$ modifikasyon uygulama ve kalite metriklerinde esneme anlamına gelmemelidir. Hastalarda işlemler öncesi enfeksiyon şüphesi oluşursa PCR için örnekleme yapılır. Yatarak tedavi görecek her hastada toraks BT çektirilir. Hastada ancak COVID19 "güvenli şekilde" ekarte edilince nöroloji birimlerine yatış verilir. Aksi halde COVID-19 ünite ve servislerine yatış yapılamalıdır. Sonuçlar çıkana kadar acil servislerdeki müstakil ortamlarda tedavinin sürdürülmesi gereklidir. COVID-19 riski, şüphesi veya varlığında süreç T.C. Sağlık Bakanlığı'nın en güncel rehberlerine göre yürütülür $(15,16)$. Burada önerilen yöntemler bu güncel rehberlerle tam bir uyum içindedir. Ancak sunulan uzman görüşleri gelişmelere tabi olarak değişim gösterebilecektir.

\section{KAYNAKLAR}

1. Cowan LT, Alonso A, Pankow JS, et al. Hospitalized Infection as a Trigger for Acute Ischemic Stroke: The Atherosclerosis Risk in Communities Study. Stroke 2016; 47(6): 16121617.

2. Sebastian S, Stein LK, Dhamoon MS. Infection as a Stroke Trigger. Stroke 2019; 50(8): 2216-2218.

3. Wang H, Li X, Yan Z, Sun X, Han J, Zhang B. Potential neurological symptoms of COVID-19. Ther Adv Neurol Disord 2020; 13(1): 1-2.

4. Wu Y, Xu X, Chen Z, et al. Nervous system involvement after infection with COVID-19 and other coronaviruses. Brain Behav Immun 2020.

5. Nath A. Neurologic complications of coronavirus infections. Neurology 2020.

6. Mao L, Wang M, Chen S, et al. Neurological Manifestations of Hospitalized Patients with COVID-19 in Wuhan, China: a retrospective case series study. medRxiv 2020; https://www.medrxiv.org/content/10.1101/2020.02.22.2 0026500v1.

7. Lyden P. Temporary Emergency Guidance to US Stroke Centers During the COVID-19 Pandemic. Stroke 2020.

8. Hassan AE, Adil MM, Zacharatos H, et al. Should ischemic stroke patients with aphasia or high National Institutes of Health stroke scale score undergo preprocedural intubation and endovascular treatment? J Stroke Cerebrovasc Dis 2014; 23(5): e299-304.

9. Baracchini C, Pieroni A, Viaro F, et al. Acute stroke management pathway during Coronavirus-19 pandemic. Neurol Sci 2020.
10. Burke JF, Chan AK, Mummaneni V, et al. Letter: The Coronavirus Disease 2019 Global Pandemic: A Neurosurgical Treatment Algorithm. Neurosurgery 2020.

11. Justin F. Fraser J, Arthur A, Chen M, Levitt M, Mocco J-ea. Society of NeuroInterventional Surgery recommendations for the care of emergent neurointerventional patients in the setting of COVID-19. http://jsnetwebsite/contents/200331/SNIS-COVIDStroke-Protocolpdf 2020.

12. Khosravani H, Rajendram P, Notario L, Chapman MG, Menon BK. Protected Code Stroke: Hyperacute Stroke Management During the Coronavirus Disease 2019 (COVID-19) Pandemic. Stroke 2020: STROKEAHA120029838.

13. Caruso D, Zerunian M, Polici M, et al. Chest CT Features of COVID-19 in Rome, Italy. Radiology 2020: 201237.

14. Faigle R, Butler J, Carhuapoma JR, et al. Safety Trial of LowIntensity Monitoring After Thrombolysis: Optimal Post Tpa-Iv Monitoring in Ischemic STroke (OPTIMIST). Neurohospitalist 2020; 10(1): 11-15.

15. TC-SAGLIK-BAKANLIGI-

HALK_SAGLIGI_GENEL_MUDURLUGU. 2019-nCoV HASTALIĞI: SAĞLIK ÇALIŞANLARI REHBERİ. https://hsgmsaglikgovtr/depo/haberler/ncov/2019nCov_Hastal_Salk_alanlar_Rehberipdf YAYIN-Ocak-2020ulașim-4-5-2020.

16. TC-SAĞLIK-BAKANLIĞI. COVID-19-SARS-CoV-2 ENFEKSIYONU REHBERİ (Bilim Kurulu Çalışması). https://covid19bilgisaglikgovtr/depo/rehberler/COVID19_Rehberipdf 2-4-2020.

17. Welt FGP, Shah PB, Aronow HD, et al. Catheterization Laboratory Considerations During the Coronavirus (COVID-19) Pandemic: From ACC's Interventional Council and SCAI. J Am Coll Cardiol 2020.

18. Han Y, Zeng H, Jiang $\mathrm{H}$, et al. CSC Expert Consensus on Principles of Clinical Management of Patients with Severe Emergent Cardiovascular Diseases during the COVID-19 Epidemic. Circulation 2020.

\section{Etik Bilgiler}

Etik Kurul Onayı: Bu makale bir tıp haberi olduğu için Etik Kurul Onayı alınmasina gerek yoktur.

Telif Hakkı Devir Formu: Tüm yazarlar tarafından Telif Hakkı Devir Formu imzalanmıștır.

Hakem Değerlendirmesi: Hakem değerlendirmesinden geçmiştir.

Yazar Katkı Oranları: Konsept: MAT, EMA, AÖÖ, Tasarım: MAT, EMA, AÖÖ, Veri Toplama veya İșleme: MAT, EMA, AÖÖ, Analiz veya Yorum: MAT, EMA, AÖÖ, Literatür Taraması: MAT, EMA, AÖÖ, Yazma: MAT, EMA, AÖÖ.

Çıkar Çatışması Bildirimi: Yazarlar çıkar çatışması olmadığını beyan etmişlerdir.

Destek ve Teşekkür Beyanı: Yazarlar bu çalışma için finansal destek almadıklarını beyan etmişlerdir. 